\section{Growth and Nutrient Status of Six Species of Nursery Stock Grown in a Compost-based Medium with Recycled Nutrients}

\author{
Calvin Chong, Glen Lumis, and Peter Purvis \\ Department of Plant Agriculture, University of Guelph, Guelph, Ontario, \\ Canada N1G 2WI
}

\author{
Adam Dale \\ Department of Plant Agriculture-Simcoe, University of Guelph, Simcoe, \\ Ontario, Canada N3Y 4N5
}

Additional index words. fertigation, woody ornamentals, nutrition, computerized injector, controlled-release fertilizer

\begin{abstract}
Rooted cuttings of 'Antonovka' apple, 'Lynwood Gold' forsythia, double-flowered kerria, common ninebark, 'Goldfinger' potentilla, and 'Red Prince' weigela were grown in 2-gal (6-L) nursery containers filled with 1:1 (by volume) of waste compost and composted pine bark, under three fertilizer regimes: 1) liquid nutrients [target concentrations in ppm $\left(\mathrm{mg}^{-1}\right)$ : $\mathrm{NH}_{4}-\mathrm{N}, 13 ; \mathrm{NO}_{3}-\mathrm{N}, 100 ; \mathrm{P}, 28 ; \mathrm{K}, 120 ; \mathrm{Ca}, 92 ; \mathrm{Mg}, 13 ; \mathrm{Fe}, 1.3 ; \mathrm{Mn}$, 0.27 ; $\mathrm{Zn}, 0.23 ; \mathrm{Cu}, 0.05 ; \mathrm{B}, 0.22 ; \mathrm{Mo}, 0.05 ; \mathrm{Na},<50 ; \mathrm{Cl},<50$; and $\left.\mathrm{SO}_{4}<300\right]$ delivered and recycled twice per day via a computer-controlled multifertilizer injector; 2) same nutrient formula and concentration rate delivered fresh via the injector but without recycling; and 3) Nutryon (Polyon) 17-5-12 controlled-release fertilizer incorporated into the medium at a rate of $11 \mathrm{lb} / \mathrm{yd}^{3}\left(6.5 \mathrm{~kg} \cdot \mathrm{m}^{-3}\right)$. With recycled liquid nutrients, all species grew the same or more than with nonrecycled nutrients, and generally the poorest growth was with controlled-release fertilizer. Foliar concentrations of $\mathbf{K}$ (all species), $\mathbf{N}$ (all species), $\mathbf{P}$ (forsythia, kerria, potentilla, and weigela), and Mn (forsythia, potentilla, and weigela) were higher in plants supplied with recycled and/or nonrecycled nutrients than in those supplied with controlled-release fertilizer, while foliar concentrations of $\mathrm{Ca}$ (ninebark and kerria) and $\mathrm{Mg}$ (apple, kerria, ninebark, potentilla, and weigela) were lower. Compared to nonrecycled liquid nutrients, the amounts of individual recycled nutrients were reduced by (percentage in brackets): $\mathrm{NH}_{4}-\mathrm{N}(30), \mathrm{NO}_{3}-\mathrm{N}(78), \mathrm{P}(76), \mathrm{K}(46), \mathrm{Ca}(93), \mathrm{Mg}(96), \mathrm{Fe}$ (52), Mn (43), Zn (55), Cu (60), B (83), and Mo (66).
\end{abstract}

Nutrient runoff into the groundwater is an important and emerging environmental issue for container nurseries (Arnold et al., 1999). Many parts of the world have introduced regulations to prevent wastewater run-off from entering the environment (Lea-Cox et al., 2001). In Canada, newly proposed nutrient management legislation in Ontario will also require farms, nurseries, and greenhouses to control and/or recycle wastewater.

Currently, some modern greenhouses recycle leachate wastewater (Papadopoulos, 1999). Unlike the greenhouse and floriculture industries, there is little information on nutrient recycling in container nursery culture (Gori and Lubello, 2000). Some container nurseries have used retention ponds to capture leachates and recycle them through the irrigation systems (Fain et al., 2000). However, without

Received for publication 8 July 2002. Accepted for publication 25 Feb. 2003. Presented in part at the $98^{\text {th }}$ Conference of ASHS, Sacramento, Calif., 22-25 July 2001. Financial support was provided by Landscape Ontario Horticultural Trades Association Growers' Group, Landscape Ontario Horticultural Trades Foundation, and the National Research Council of Canada, Industrial Research Assistance Program(IRAP). Technical assistance was provided by Eric Labbate. the proper equipment, it is labour-intensive to recycle wastewater and difficult to achieve a proper nutritional balance.

A patented, computer-controlled multifertilizer injector, initially designed and tested to fertigate greenhouse-grown vegetables (Papadopoulos and Liburdi, 1989) was used by Purvis et al. $(1998,2000)$ to recycle nutrient runoff from one test species in an experimental container nursery.

The objectives of this research were (a) to evaluate growth and nutrient status of six container-grown crops in response to recycled liquid nutrients using an upgraded fertilizer injector, and to compare these responses with crops grown without recycled liquid nutrients or with traditionally used controlled-release fertilizer; and (b) to check the accuracy of the upgraded injector.

\section{Materials and Methods}

The injector. The injector system was previously described by Purvis et al. (1998; 2000). It consisted of a two-tiered stainless steel frame $(1.2 \mathrm{~m}$ long $\times 1.4 \mathrm{~m}$ high $\times 0.5 \mathrm{~m}$ wide $)$ mounted with 10 electrically-driven, individually-controlled dosimetric injection pumps. Each pump dispensed a separate stock solution of nutrients or acid. The injector housed in-line EC, $\mathrm{pH}$, and flow sensors and two nutrient blending tubes connected in series. The system was upgraded to allow more effective mixing and dispensing of recycled nutrients, fresh water, or both, by including: two 1387-L above-ground storage tanks (one for leachate wastewater and the other for fresh water) located adjacent to the injector; a three-way blending valve; a second electrical conductivity (EC) meter; and new software (version 6.51; Climate Control Systems, 2000).

Plant material and substrate. On 5 July 2000, bare-rooted liners of apple (Malus Mill 'Antonovka') and plug-rooted cuttings of forsythia (Forsythia $\times$ intermedia Zab. 'Lynwood Gold'), double-flowered kerria [Kerria japonica (L.) DC. 'Pleniflora'], common ninebark [Physocarpus opulifolius (L.) Maxim.], potentilla (Potentilla fruticosa L. 'Goldfinger'), and weigela [Weigela florida (Bunge) A. DC. 'Red Prince'], were transplanted into 6-L (21 $\mathrm{cm}$ diameter $\times 21 \mathrm{~cm}$ deep) nursery containers filled with $1: 1$ by volume waste compost (leaf and yard waste, 5-mm sieve size; Metro Toronto Keele Valley Landfill, Ont.) and composted pine bark (Waterdown Garden Supplies, Ont.) and grown for 14 weeks. The chemical analysis of the growing medium ingredients are shown in Table 1.

Treatments and cultural practices. The containerized plants were grown under three fertilizer regimes: 1) water soluble fertilizer based on a targeted nutrient formula (Table 2) delivered and recycled via the injector; 2) same formula delivered fresh via the injector but without recycling; and 3) Nutryon (Polyon) 17-5-12 (17N-2P-10K) 6-month controlledrelease fertilizer plus micronutrients (Hydro Agri Canada, Ont.) incorporated into the substrate at a rate of $6.5 \mathrm{~kg} \cdot \mathrm{m}^{-3}$. The nutrient solutions to treatments 1 and 2, as well as fresh water only to treatment 3 , were delivered by the injector at a rate of $6 \mathrm{~L} / \mathrm{h}$ for 10 min twice daily via one Acu-Spray stick emitter (Nibco, Fresno, Calif.) per container.

The experiment was laid out as a split-plot design with fertilizer treatments as main plot and species as subplot. There were four main plot replications and four plants of each species per subplot. Spacing was $48 \mathrm{~cm}$ between pots. Plants grown without recycling (treatments 2 and 3) were placed on a crushed gravel base and leachate wastewater from the containers was allowed to run off into the ground. Plants grown with recycled nutrients (treatment 1 ) were placed on $2 \%$ sloped aluminum troughs ( $22 \mathrm{~cm}$ wide $\times 4 \mathrm{~cm}$ deep $\times 10 \mathrm{~m}$ long), which directed the leachate wastewater into a $1800-\mathrm{L}$ in-ground collection pit. The pit was covered with black fabric to prevent algae growth.

The wastewater was pumped from the collection pit to the indoor wastewater tank. Each week samples of wastewater from this tank were analysed (Agri-Food Laboratories, Guelph, Ont.) for $\mathrm{pH}, \mathrm{EC}, \mathrm{NO}_{3}-\mathrm{N}, \mathrm{NH}_{4}-\mathrm{N}, \mathrm{P}$, $\mathrm{K}, \mathrm{Ca}, \mathrm{Mg}, \mathrm{Fe}, \mathrm{Mn}, \mathrm{Zn}, \mathrm{Cu}, \mathrm{B}, \mathrm{Mo}, \mathrm{Na}, \mathrm{Cl}$, and $\mathrm{SO}_{4}$ and the values re-programmed into the computer. Based on these laboratory results, the wastewater was blended at each fertigation with $20 \%$ fresh water and pumped to the 
Table 1. Chemical analysis of the growing medium ingredients before mixing.

\begin{tabular}{lcllrrrlllllr}
\hline Medium & \multicolumn{11}{c}{ Nutrients $^{\mathrm{z}}\left(\mathrm{mg} \cdot \mathrm{L}^{-1}\right)$} \\
\cline { 2 - 12 } ingredients & $\mathrm{NH}_{4}-\mathrm{N}$ & $\mathrm{NO}_{3}-\mathrm{N}$ & $\mathrm{P}$ & $\mathrm{K}$ & $\mathrm{Ca}$ & $\mathrm{Mg}$ & $\mathrm{Fe}$ & $\mathrm{Mn}$ & $\mathrm{Zn}$ & $\mathrm{Cu}$ & $\mathrm{Na}$ & $\mathrm{Cl}$ \\
\hline Waste compost & $108^{\mathrm{y}}$ & 0.6 & 1 & 1310 & 166 & 62 & 0.3 & 0.1 & 0.1 & 0.3 & 103 & 769 \\
SE & 1 & 0.01 & 0.02 & 10 & 4 & 1 & 0.01 & 0.01 & 0.03 & 0.1 & 1 & 3 \\
Pine bark & 1 & 1.3 & 0.1 & 10 & 13 & 3 & 1 & 0.1 & 0.2 & 0.1 & 1.5 & 3 \\
SE & 0.05 & 0.7 & 0 & 2 & 3 & 0 & 0.1 & 0 & 0.06 & 0 & 0.5 & 0.8 \\
\hline
\end{tabular}

${ }^{2}$ Concentration of nutrients measured using saturated medium extraction procedure.

${ }^{y}$ Each datum is the mean of three samples \pm standard error (SE).

Table 2. The $\mathrm{pH}, \mathrm{EC}$, and concentration of nutrients delivered by the injector and in the leachate wastewater from six species of container-grown nursery stock.

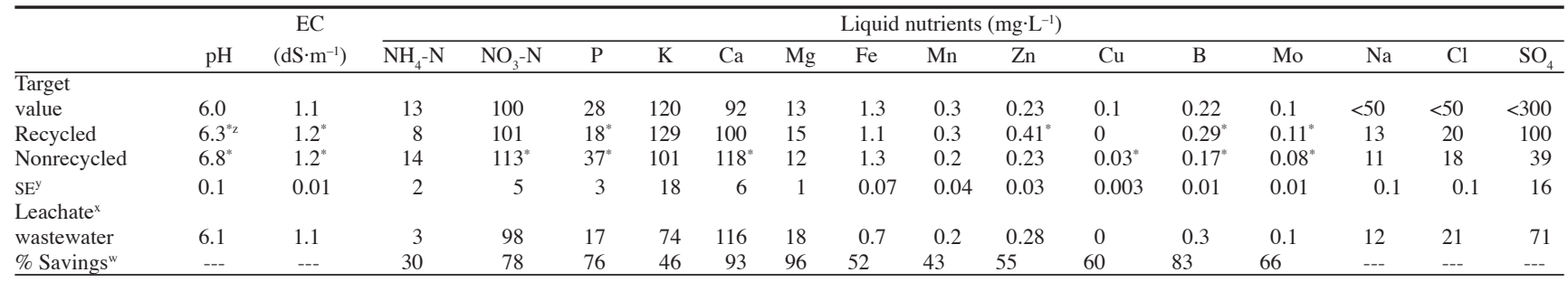

${ }^{2}$ Each datum is the mean over 3 sampling dates (11 Aug., 31 Aug. and 4 Oct.) measured at the emitter just before entering the substrate. The asterisk indicates significant difference $(P \leq 0.05)$ from target value at $95 \%$ confidence limit.

${ }^{y}$ Common standard errors of the recycled and nonrecycled means.

${ }^{x}$ Sampled from the indoor wastewater tank.

${ }^{\mathrm{w}}($ Concentration in leachate wastewater $\times 0.8 /$ concentration in recycled nutrients $) \times 100$.

injector, where the nutrients were replenished to the targeted values (Table 2) before being dispensed to the crops. The fresh water (municipal source) for blending and irrigation was initially pre-programmed into a computer file to account for the following chemical contents, in $\left(\mathrm{mg} \mathrm{L}^{-1}\right): \mathrm{NH}_{4}-\mathrm{N}, 0.1 ; \mathrm{NO}_{3}-\mathrm{N}, 4 ; \mathrm{P}, 0.1 ; \mathrm{K}, 2$; $\mathrm{Ca}, 34 ; \mathrm{Mg}, 9 ; \mathrm{Fe}, 0.1 ; \mathrm{Mn}, 0.002 ; \mathrm{Zn}, 0.004$; $\mathrm{Cu}, 0.003 ; \mathrm{B}, 0.004 ; \mathrm{Mo}, 0.004$; and $\mathrm{SO}_{4}, 57$. The $\mathrm{pH}$ was 7.3 and the EC was $0.3 \mathrm{dS} \cdot \mathrm{m}^{-1}$.

Nutrient, plant, and substrate samples. On 11 Aug., 31 Aug., and 4 Oct., samples of the dispensed nutrients in each replication were collected from fertilizer treatments 1 and 2 at the emitter (just before solutions entered the substrate) and analysed for $\mathrm{pH}, \mathrm{EC}$, and nutrients as described above. On 10 July, 8 Aug., and 28 Aug., samples of the substrate collected from a 7- to $12-\mathrm{cm}$ depth in containers of all treatments and replications were analysed for $\mathrm{pH}$ and EC using 1:2 medium:water (vol/vol) extracts. On 15 Sept., samples (each 20-30 g fresh weight composited from the four plants in each subplot) of recently matured leaves were collected, oven-dried, ground (40 mesh), and analyzed in three of the replications for $\mathrm{N}, \mathrm{P}, \mathrm{K}, \mathrm{Ca}, \mathrm{Mg}, \mathrm{Fe}, \mathrm{Mn}$, and Zn. On 10 Oct., the top of each plant (stem plus leaves) was removed, dried, and weighed.

Statistical analysis. The accuracy of EC and of the concentration of each dispensed nutrient was compared to targeted values using $95 \%$ confidence limits. The saving of each nutrient with recycling was calculated as follows: (nutrient concentration in leachate wastewater $\times 0.8$ /nutrient concentration with recycling) $\times 100$, where 0.8 in the numerator represents the adjustment factor for blending with $20 \%$ by volume of fresh water. Data for top dry weight, foliar nutrients, and substrate $\mathrm{pH}$ and $\mathrm{EC}$ were subjected to analysis of variance. The top dry weight and concentration of each foliar nutrient were correlated for each species. Other relationships among the foliar nutrients and species were examined by principal component analysis (SAS, 1994), and the resulting principal component scores examined by analysis of variance. Principal component analysis restructures data sets containing many correlated variables into smaller independent data sets that can be analysed by univariate methods. The principal component vectors, which are orthogonal to each other, are described by weightings of the original correlated variables, and are ordered by the declining proportion of the total variance they account for. These weightings may suggest biological meanings for the groupings of the variables. The individual scores or values for each data point in each principal component are computed from the individual vector weightings and represent derived variables (Iezzoni and Pritts, 1991).

\section{Results and Discussion}

Nutrient delivery. The EC values of the dispensed nutrients were similar in the recycled and nonrecycled liquid treatments $\left(1.2 \mathrm{dS} \cdot \mathrm{m}^{-1}\right.$, mean over three dates) and significantly higher than the targeted value $\left(1.1 \mathrm{dS} \cdot \mathrm{m}^{-1}\right)$ (Table 2$)$. With recycling, the concentration of dispensed $\mathrm{P}$ was lower than the target value while corresponding concentration of $\mathrm{Zn}, \mathrm{B}$, and Mo were higher. Without recycling, the concentrations of dispensed $\mathrm{Cu}$ and $\mathrm{B}$ were lower while those of $\mathrm{NO}_{3}-\mathrm{N}, \mathrm{P}, \mathrm{Ca}$, and $\mathrm{Mo}$ were higher than targeted values. Values for $\mathrm{Na}, \mathrm{Cl}$, and $\mathrm{SO}_{4}$ were well below targeted thresholds. Although the target $\mathrm{pH}$ for dispensed nutrients was 6.0, due to a malfunction in the electrode, the actual values at the computer were unknown. Values at the emitter were 6.3 for recycled vs. 6.8 for nonrecycled nutrients.

Plant response. The main effect of fertilizer treatments (Table 3) indicated that recycled liquid nutrients provided the best overall top growth, followed by nonrecycled liquid nutri- ents, and controlled-release fertilizer. Where the nutrients were recycled, plants either grew similar to (forsythia, kerria, and weigela) or more than (apple, ninebark, and potentilla) those where the nutrients were not recycled. All plants supplied with liquid nutrients grew more than those supplied with controlled-release fertilizer, although in the case of apple where nutrients were not recycled, this difference was nonsignificant.

Foliar concentrations of $\mathrm{K}$ (all species), $\mathrm{N}$ (all species), $\mathrm{P}$ (forsythia, kerria, potentilla, and weigela), and Mn (forsythia, potentilla, and weigela) were higher in plants supplied with recycled and/or nonrecycled nutrients than in those supplied with controlled-release fertilizer (Table 3). There was a reverse trend for $\mathrm{Ca}$ (ninebark and kerria) and $\mathrm{Mg}$ (apple, kerria, ninebark, potentilla, and weigela). Foliar $\mathrm{Fe}$ and $\mathrm{Zn}$ concentrations were unaffected by fertilizer treatments.

Positive correlations $(* * P \leq 0.01$ or $* P$ $\leq 0.05, \mathrm{n}=9$ ) were found between top dry weight and the following foliar nutrients: $\mathrm{N}$ (forsythia, $r=0.86 * *$; ninebark, $r=0.79$ *; and weigela, $r=0.79 *$ ); $\mathrm{P}$ (weigela, $r=$ $0.87 * *$ ); $\mathrm{K}$ ( forsythia, $r=0.73 *$; ninebark, $r=0.91 * *$; and weigela, $r=0.84 * *) ; \mathrm{Mn}$ (potentilla, $r=0.89 * *$; and weigela, $r=0.73$ *). There were negative correlations for: $\mathrm{Mg}$ (forsythia, $r=-0.73 *$; kerria, $r=-0.98 * *$; and ninebark, $r=-0.90 * *$ ); and $\mathrm{Ca}$ (ninebark, $r=-0.89 * *)$

In the present study, nutrient recharge was based on a targeted EC value of $1.1 \mathrm{dS} \cdot \mathrm{m}^{-1}$ plus the combined targeted value for each of the 15 nutrients (Table 2). Only $\mathrm{P}, \mathrm{Ca}$, and some micronutrients departed from target values (Table 2). These differences were considered to be relatively small and/or innocuous and perhaps could be ascribed in part to the inherent variability in recycling associated with extra pumping and blending, calibration of meters or with impurities inherent in the stock nutrients 
Table 3. Top dry weight and foliar nutrient concentrations of six species of container-grown nursery stock in response to three fertilizer treatments.

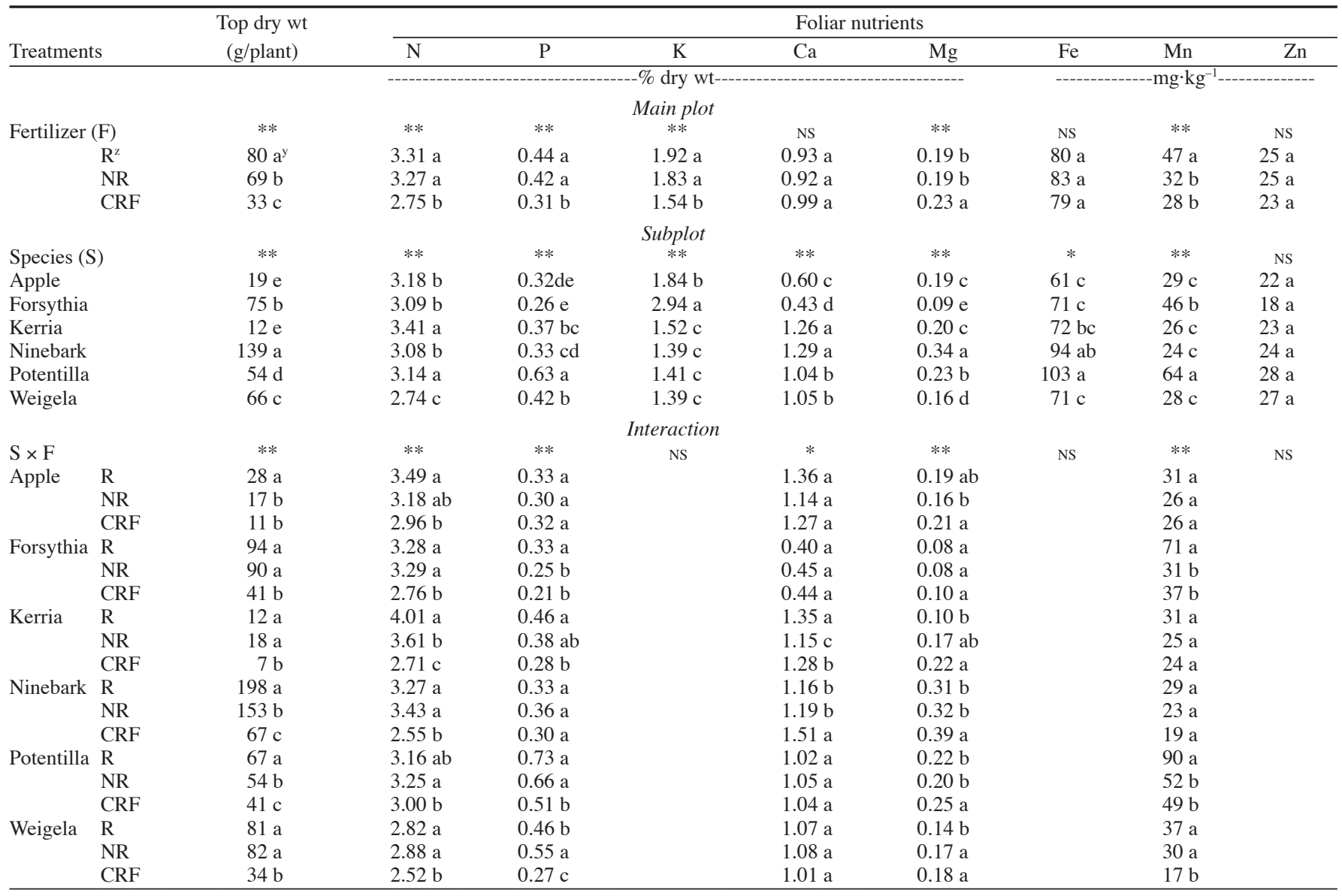

${ }^{2} \mathrm{R}=$ recycled liquid nutrients; $\mathrm{NR}=$ nonrecycled liquid nutrients; and $\mathrm{CRF}=$ controlled-release fertilizer.

${ }^{y}$ Means within a column for main plot (fertilizer), subplot (species) or interaction $(\mathrm{S} \times \mathrm{F})$ with different letters $(\mathrm{a}-\mathrm{e})$ are significantly different by LS means at $P \leq 0.05$.

Ns, ${ }^{* *}, *$ Nonsignifcant or significant at $P \leq 0.01$ or 0.05 , respectively.

particularly regarding micronutrients (Papadopoulos and Khosla, 1995). The upgraded injector performed more effectively and accurately than the previous version (Purvis et al., 2000), where the nutrient recharge of the leachate wastewater was based solely on a targeted EC value of $1.85 \mathrm{dS} \cdot \mathrm{m}^{-1}$, and the injector dispensed considerably less $\mathrm{NH}_{4}-\mathrm{N}, \mathrm{NO}_{3}-\mathrm{N}$, $\mathrm{P}$, and $\mathrm{K}$ than targeted values. Using a similar injector but without our upgrade, Papadopoulos and Khosla (1995) described wide variability in dispensed $\mathrm{N}, \mathrm{P}, \mathrm{K}, \mathrm{Ca}, \mathrm{Mg}$, and Fe. Nitrogen was nearly always at lower concentrations and Pat higher concentrations than targeted values. In our present study, there was a noticeable increase in $\mathrm{SO}_{4}$ in the recycled solution (Table 2). According to Zekki et al. (1996), certain elements, such as $\mathrm{SO}_{4}$, have a tendency to accumulate in recycled solutions.

On 10 July (5 days after planting), substrate EC in the controlled-release fertilizer treatment was twice $\left(0.56 \mathrm{dS} \mathrm{m}^{-1}\right)$ those with nutrient recycling $\left(0.27 \mathrm{dS} \cdot \mathrm{m}^{-1}\right)$ and non-recycling $\left(0.28 \mathrm{dS} \cdot \mathrm{m}^{-1}\right)$ but showed no differences among fertilizer treatments on the other two sampling dates (8 Aug., $0.26 \mathrm{dS} \cdot \mathrm{m}^{-1}$ and $28 \mathrm{Aug} ., 0.36$ $\left.\mathrm{dS} \cdot \mathrm{m}^{-1}\right)$. Factors such as the chemical and physical properties of the medium, irrigation practices, and weather-related variables have important effects on the retention or release of nutrients (Whitcomb, 1988). In particular, the leaching of nutrients from controlled-release fertilizer can significantly affect how plants respond to this treatment.

While the compost-based substrate per se may have contributed extra amounts of nutrients such as $\mathrm{NH}_{4}-\mathrm{N}, \mathrm{K}, \mathrm{Ca}$, and $\mathrm{Mg}$ (Table 1), their contribution to overall plant growth is perhaps very minimal and occurred primarily during a relatively brief period after potting. Results from previous studies under similar cultural conditions indicate that (a) the soluble salts in a wide variety of compost-based media have typically declined by as much as $80 \%$ within days after potting (Chong, 1999a), and (b) this $1: 1$ by volume compost; bark medium has a relatively high $(40 \%-50 \%)$ leaching fraction (Gils et al., 2003) and is quite porous (total porosity, $60 \% \pm 1 \%$; aeration porosity, $33 \% \pm$ $1 \%$; water retention capacity, $27 \% \pm 1 \%$; bulk density, $0.37 \pm 0.01 \mathrm{~g} \mathrm{~cm}^{-3}$ ). During most of the study period, rainfall of $58,67,74$, and 30 $\mathrm{mm}$ in July, August, September, and October, respectively, was close to the long-term (65year) averages of $65,77,76$, and $58 \mathrm{~mm}$ for the same months. Furthermore, the irrigation and fertilizer volumes were applied automatically twice daily, rain or shine. This evidence may explain in part why the substrate EC values showed no apparent and direct relationship with fertilizer and/or species responses. Despite the fact that rain water (undetermined amount) was allowed to drain into the outdoor collection tank, the tank never overflowed. There was little variability in wastewater EC and nutrient concentrations during the period of study, confirming our previous work (Purvis et al., 2000).

Substrate $\mathrm{pH}$ declined slightly from 7.7 on 10 July to 7.4 at the end of August, and values were similar among fertilizer treatments. Our experience with container-grown nursery crops has shown that this small difference in substrate $\mathrm{pH}$, as also that measured between the recycled and nonrecycled nutrients (Table 2), should have no noticeable effect on plant growth response (Chong, 1999a). While substrate $\mathrm{pH}$ above 7.0 could be considered too high for standard nursery growing conditions (5.5-7.0 recommended range; OMAFRA, 2000), increasingly, research has been demonstrating that many nursery crops can be successfully grown in waste-derived compost substrates with initial $\mathrm{pH}$ in excess of 8.0 (Chong, 2000).

While we did not measure the light or temperature within the proximity of plants growing on crushed gravel vs. aluminum troughs, any differences would appear to be minimal and mitigated by the narrowness of the troughs, 
the light color of the gravel, and the relatively wide spacing between plants. Growth response was similar to our previous work (Purvis et al., 2000) where ninebark grew better with recycled nutrients than those supplied with nonrecycled nutrients and with slow-release fertilizer, in that order. Also similar to results for this and other species (Table 3), researchers have reported increased (McLachlan, 2002) or similar (Hicklenton, 1982) growth of container-grown woody plants supplied with liquid nutrients compared with controlled-release fertilizers, although controlled-release fertilizers sometimes perform better (Murray et al., 1996). Interestingly, growth of forsythia, ninebark, and weigela was consistently and positively correlated with foliar concentrations of $\mathrm{N}$ and $\mathrm{K}$ and negatively correlated with $\mathrm{Mg}$ (all three species) and $\mathrm{Ca}$ (ninebark only). The various interactions between species and fertilizer treatments and the inconsistency in correlation between growth and individual foliar nutrient concentrations are typically what researchers have observed since there apparently is no unique or single relationship which describes foliar nutrient concentration and crop response to fertilizers (Al-Jaloud et al., 1995; Walworth and Sumner, 1988). Principal component analysis of the foliar nutrients indicated a complex interrelationship in which the first three components accounted for $79 \%$ of the variance (Fig. 1). The other five principal components each contributed $<8 \%$.

The first principal component had a vector loading for $\mathrm{K}$ opposite to approximately equal loadings for $\mathrm{P}, \mathrm{Ca}, \mathrm{Mg}, \mathrm{Fe}$, and $\mathrm{Zn}$ (Fig. $1)$. The mean scores of the component only varied significantly among species (Table 4). The second principal component had the $\mathrm{Ca}$ and $\mathrm{Mg}$ loadings opposed to the others (Fig. 1). Fertilizer, species and their interaction all varied significantly (Table 4). However, the interaction accounted for significantly less variation than the two main effects. The controlled-release fertilizer had the lowest score of the three fertilizers.

Nursery crops vary widely in nutritional requirements and direct comparisons between experiments are difficult due to differences in procedures and cultural conditions (Wright and Niemiera, 1987). According to these authors, recommendations for $\mathrm{Ca}$ and $\mathrm{Mg}$ in the substrate solutions typically vary from a fraction to several parts per million, but may be as high as 350 and $100 \mathrm{ppm}\left(\mathrm{mg} \mathrm{L}^{-1}\right)$, respectively. According to A. Gallant (personal communication), $\mathrm{Ca}$ and $\mathrm{Mg}$ are included uncoated in controlled-release formulations such as Nutryon $17-5-12$ in limited amounts $(1.1 \%$ and $0.65 \%$, respectively), since these nutrients are present often in sufficient amounts in most sources of irrigation water, including the present municipal source used in this experiment $(\mathrm{Ca}, 34$ and $\left.\mathrm{Mg}, 9 \mathrm{mg} \cdot \mathrm{L}^{-1}\right)$. For $\mathrm{K}, 25-50 \mathrm{ppm}\left(\mathrm{mg} \mathrm{L}^{-1}\right)$ are usually adequate but concentrations may be as high as $120 \mathrm{ppm}\left(\mathrm{mg} \cdot \mathrm{L}^{-1}\right)$ for certain species (Wright and Niemiera, 1987). This evidence suggests that the concentrations of $\mathrm{K}$ in our solution (Table 2), originally developed for container-grown rose (Blom et al., 1990), may have been excessive particularly for forsythia
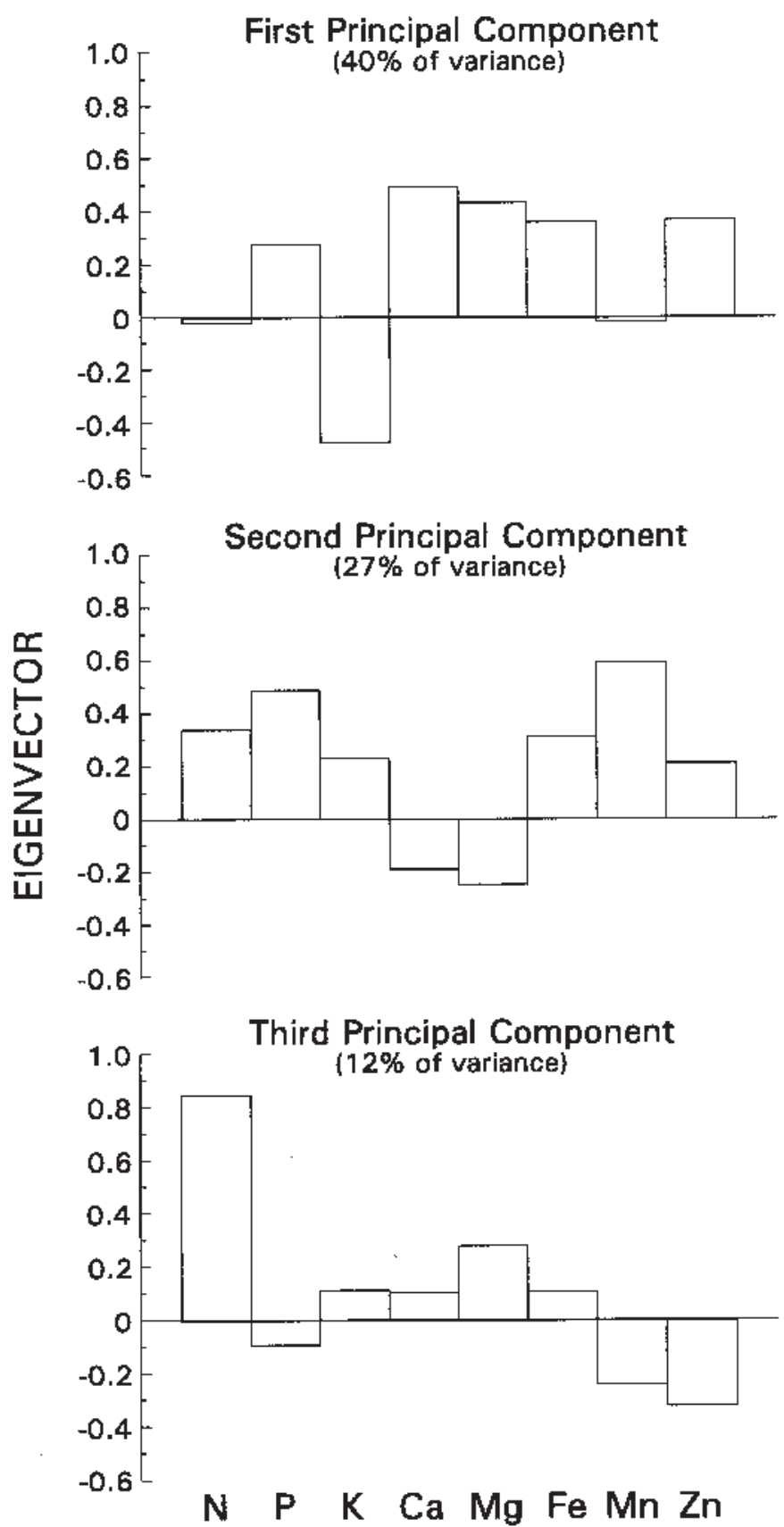

Fig. 1. Eigenvectors for the first three principal components of the foliar nutrients from six species of container-grown nursery stock in response to three fertilizer treatments.

(Tables 3 and 4). Excess K causes "luxury consumption" of K which may interfere with the availability of $\mathrm{Ca}$ and $\mathrm{Mg}$ (Marschner, 1995). The species scores for the first principal component corroborates this hypothesis, suggesting that in future studies, the concentration of $\mathrm{K}$ should be reduced even further, particularly for forsythia. Notwithstanding the above results, there were no visual signs of nutrient toxicity or deficiency in plants from any of the fertilizer treatments or species.

The third principal component expressed mainly variation in foliar N (Fig. 1). Fertilizer, species, and interaction all varied significantly, and the scores for fertilizer (Table 4) were correlated with top dry weight (Table 3 ). The result of this component seemed to be reflecting dif- ferences in availability or uptake of nutrients, primarily $\mathrm{N}$, from the liquid treatments (same quantities provided daily) vs. more restricted or variable amounts from the controlled-release Nutryon. In previous studies, we advocated the use of blended controlled-release fertilizers to provide quicker or more sustained release of nutrients for increased growth (Chong, 1999b).

Comparable in magnitude to our previous results (Purvis et al., 2000), the amounts of $\mathrm{NH}_{4}-\mathrm{N}, \mathrm{NO}_{3}-\mathrm{N}, \mathrm{P}$, and $\mathrm{K}$ used were reduced by $30 \%, 78 \%, 76 \%$, and $46 \%$, respectively, by recycling nutrients (Table 2). Percent savings for other nutrients were: $\mathrm{Ca}$ (93), Mg (96), Fe (52), Mn (43), Zn (55), Cu (60), B (83), and Mo (66). 
Table 4. Scores of the first three principal components of the foliar nutrients from six species of container-grown nursery stock in response to three fertilizer treatments.

\begin{tabular}{|c|c|c|c|}
\hline \multirow[b]{2}{*}{ Treatments } & \multicolumn{3}{|c|}{ Principal component scores } \\
\hline & First & Second & Third \\
\hline \multicolumn{4}{|c|}{ Main plot } \\
\hline Fertilizer $(\mathrm{F})$ & NS $(0.38)^{\mathrm{z}}$ & $* *(10.83)$ & $* *(2.96)$ \\
\hline $\mathrm{R}^{\mathrm{y}}$ & $-0.03^{x}$ & $1.08 \mathrm{~b}$ & 0.27 \\
\hline NR & -0.21 & $0.32 \mathrm{a}$ & 0.42 \\
\hline CRF & 0.15 & $-1.01 \mathrm{c}$ & -0.53 \\
\hline \multicolumn{4}{|c|}{ Subplot } \\
\hline Species (S) & $* *(19.33)$ & ${ }^{* *}(7.21)$ & ${ }^{* *}(2.64)$ \\
\hline Apple & $-1.09 \mathrm{c}^{\mathrm{x}}$ & $-0.30 \mathrm{c}$ & $0.23 \mathrm{a}$ \\
\hline Forsythia & $-3.00 \mathrm{~d}$ & $0.78 \mathrm{~b}$ & $-0.13 \mathrm{~b}$ \\
\hline Kerria & $3.00 \mathrm{~b}$ & $-0.36 \mathrm{c}$ & $0.94 \mathrm{a}$ \\
\hline Ninebark & $1.54 \mathrm{a}$ & $-1.00 \mathrm{~d}$ & $0.68 \mathrm{a}$ \\
\hline Potentilla & $1.59 \mathrm{a}$ & $1.90 \mathrm{a}$ & $-0.30 \mathrm{~b}$ \\
\hline Weigela & $0.48 \mathrm{~b}$ & $-0.24 \mathrm{c}$ & $-1.08 \mathrm{c}$ \\
\hline \multicolumn{4}{|c|}{ Interaction } \\
\hline$\underline{S} \times \mathrm{F}$ & NS $(0.59)$ & ${ }^{* *}(0.86)$ & ${ }^{* *}(0.82)$ \\
\hline 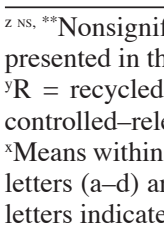 & $\begin{array}{l}\text { significant } \\
\text { s. } \\
\text { utrients; NR } \\
\text { izer. } \\
\text { for main plo } \\
\text { cantly differe } \\
\text { iificance at } P\end{array}$ & $\begin{array}{l}1, \text { respectiv } \\
\text { ycled liquic } \\
\text { r) or subplo } \\
\text { neans at } P\end{array}$ & $\begin{array}{l}\text { n square is } \\
\text { nd CRF = } \\
\text { th different } \\
\text { nn without }\end{array}$ \\
\hline
\end{tabular}

\section{Conclusion}

With recycled liquid nutrients, three species of container-grown crops (forsythia, kerria, and weigela) grew more than those grown with nonrecycled liquid nutrients, while growth of three other species (apple, ninebark, and potentilla) grew similar to those grown with nonrecycled liquid nutrients. Plants supplied with liquid nutrient treatments generally contained higher concentrations of foliar N, K, and to a lesser extent $\mathrm{P}$ and $\mathrm{Mn}$, and generally outgrew those supplied with controlled-release fertilizer. Substantial savings were realized in the amounts of nutrients utilized due to recycling. The upgraded injector delivered nutrients more accurately than the previous version.

\section{Literature Cited}

Al-Jaloud, A.A., G. Hussain, A.J. Al-Saati, and S. Karimulla. 1995. Effect of wastewater irrigation on mineral composition of corn and sorghum plants in a pot experiment. J. Plant Nutr. 18: 1677-1692.

Arnold, M.A., B.J. Lesikar, A.L. Kenimer, and D.C. Wilkerson. 1999. Spring recovery of constructed wetland plants affects nutrient removal from nursery runoff. J. Environ. Hort. 17:5-10.
Blom, T., T. Weiger, and B. Spaulding. 1990. Computer-assisted calculation for optimized crop nutrition. Software. Roses Inc., Haslett, Mich.

Chong, C. 1999a. Experiences with the utilization of wastes in nursery potting mixes and as field soil amendments. Can. J. Plant Sci. 79:139-148.

Chong, C. 1999b. Blending slow-release fertilizers for container nursery culture. Comb. Proc. Intl. Plant Prop. Soc. 49:287-292.

Chong, C. 2000. Response of containerized nursery crops to level of turkey litter compost and time of fertilizer application, p. 917-933. In : P.R. Warman and B.R. Taylor (eds.). Proc. of the Intl. Composting Symp. (ICS 99), vol. I. CBA Press, Truro, N.S.

Climate Control Systems. 2000. Fertigation Manager user manual version 6.31 and 6.51. Climate Control Systems, Ontario.

Fain, G.B., C.H. Gilliam, K.M. Tilt, J.W. Olive, and B. Wallace. 2000. Survey of best management practices in container production nurseries. $\mathrm{J}$. Environ. Hort. 18:142-144.

Gils, J., C. Chong, and G. Lumis. 2003. Container nursery stock response to recirculated nutrients. Acta Hort. (In press.)

Gori, R. and C. Lubello. 2000. Pilot plant for reclaimed wastewater reuse in nurseries. Water Sci. and Technol. 42:221-226.

Hicklenton, P.R. 1982. Nitrogen and potassium nutrition in relation to growth of Andorra juniper in a sawdust-sphagnum peat medium. HortScience 17:355-358.

Iezzoni, A.F. and M.P. Pritts. 1991. Applications of principal component analysis to horticultural research. HortScience 26:334-338.

Lea-Cox, J.D., D.S. Ross, and K.M. Teffeau. 2001. A water and nutrient management planning process for container nursery and greenhouse production systems in Maryland. J. Environ. Hort. 19:230-236.

Marschner, H. 1995. Mineral nutrition of higher plants. $2^{\text {nd }}$ ed. Academic, San Diego.

McLachlan, K.L. 2002. An investigation of watersoluble constituents in anaerobic digestates and growth substrates. M.Sc. Thesis, Univ. of Guelph.

Murray, C.L., G.P. Lumis and C. Chong. 1996. Fertilizer method and container size effects on shade trees grown in in-ground containers. Can. J. Plant Sci. 76:507-513.

Ontario Ministry of Agriculture, Food and Rural Affairs. 2000. Nursery and landscape plant production. Publ. 383. Queen's Printer for Ontario, Toronto, Ontario.

Papadopoulos, A.P. (ed.). 1999. Proceedings of the international symposium on growing media and hydroponics, Vol. I and II, Windsor, Ontario, 19-26 May 1997. Intl. Soc. Hort. Sci., Belgium.

Papadopoulos, A.P. and S. Khosla. 1995. Concepts and methodology for fertilizer use economy in greenhouse tomato production in Canada. Acta Hort. 401:461-471.

Papadopoulos, A.P. and N. Liburdi. 1989. The Harrow Fertigation Manager-A computer controlled multifertilizer injector. Acta Hort. 260:255-265.

Purvis, P., C. Chong, and G.P. Lumis. 1998. A new computer controlled multifertilizer injector for recycling nutrients and water run-off in nurseries. Comb. Proc. Intl. Plant Prop. Soc. 48:150-152.

Purvis, P., C. Chong, and G.P. Lumis. 2000. Recirculation of nutrients in container nursery production. Can. J. Plant Sci. 80:39-45.

SAS Institute. 1994. SAS/STAT user's guide, version 6. $4^{\text {th }}$ ed., vol. I. SAS Inst., Cary, N.C.

Walworth, J.E. and M.E. Sumner. 1988. Foliar diagnosis: A review, p. 193-142. In: B. Tinker and Läuchli (eds.). Advances in plant nutrition, Vol. 13, New York.

Whitcomb, C. 1988. Plant production in containers. Lacebark Pub., Stillwater, Okla.

Wright, R.D. and A.X. Niemiera. 1987. Nutrition of container-grown woody nursery crops. Hort. Rev. 9:75-101.

Zekki,H.,L. Gauthier, and A. Gosselin. 1996. Growth productivity and mineral composition of hydroponically cultivated greenhouse tomatoes, with or without nutrient solution recycling. J. Amer. Soc. Hort. Sci. 12:1082-1088. 